\title{
Yield Gap Analysis of TBG-104 (Blackgram variety) in Southern Zone of Andhra Pradesh
}

\author{
P. Lavanya Kumari ${ }^{1 *}$ and L. Prasanthi ${ }^{2}$ \\ ${ }^{1}$ Department of Statistics and Computer Applications, ${ }^{2}$ Director of Research, Regional \\ Agricultural Research Station Tirupati, ANGRAU, Andhra Pradesh, India \\ *Corresponding author
}

\begin{tabular}{|l|}
\hline K e y w o r d s \\
Yield gap, \\
TBG-104, \\
Contributing factors \\
\hline Article Info \\
\hline $\begin{array}{l}\text { Accepted: } \\
\text { 15 August } 2020 \\
\text { Available Online: } \\
\text { 10 September } 2020\end{array}$ \\
\hline
\end{tabular}

\section{Introduction}

The concept of yield gap is one of the important challenges faced in the Agricultural Sector. However, a gap always prevails between what is projected as the potential yield of any variety at research station and what is obtained in organized farm trials and
Yield gap analysis is an increasingly popular concept in agriculture sector.It is always a matter of concern for the research managers, agriculture scientists and development administrators to ensure that the real potential of any crop variety is harvested at the farmers' field. Further, contributing factors for the yield gap is also very important to manage the higher yields positively. In this study, Yellow mosaic resistant, TBG-104, a new variety of blackgram is considered which showed a higher yield gap between potential yield given by the breeder and the actual yield realized in the farmers' fields during rabi season. Surprisingly, on an average 1.5 folds more yield is observed in the famers' fields. A random sample of fifty-two farmers who cultivate TBG-104 was selected from three districts of Southern Zone of Andhra Pradesh and their fields are monitored from sowing to harvesting and data is collected on six factors. Out of six factors, two factors viz., two micronutrient sprays along with pesticide application at recommended level $\left(\mathrm{MN}_{2}\right)$ and providing supplement irrigation in crucial stages of the crop have been identified as significant contributors in realizing higher yields of the variety. From the regression model it is noticed that the average yield of this variety is 4.9 quintals per acre irrespective of other management practices if pest is not infected. By providing supplement irrigation, nearly 1.5 quintals per acre can be protected while 2.7 quintals per acre can be protected with the application of two sprays of micronutrients and usage of pesticides. Hence, this variety can achieve its potentiality in congenial environment with scrupulous crop management i.e. application of nutrients and insect control and providing supplemental irrigation at crucial stages of crop growth. 
development and investment also. There are number of empirical evidences pertaining to yield gap analysis in agricultural crop like wheat, cotton, rice etc. (Aggrawal et al., 2008). Kiresur et al., (2001) analysed profitability and Girish Kumar Jha et al., (2012) worked on sustainability of improved oilseeds production technologies for eight oilseeds crops. This study also helps to improve the efficiency of land and labour use, reduce production cost and increase food security.

It is also an important aspect to be considered by the scientists and administrators as the post follow-up action after releasing any variety whether the actual potentiality of that variety is being realised by the farmers with the suitable managing practices or not. At this juncture, a typical study is planned with the objectives includes to identify the major crop variety which has more yield gap. To explore the significant factors for the yield gap. And also to provide suggestions in retrieving the yields at its potential level.

Singh et al., (2007) described two types of yield gap in terms of technological and extension yield gaps using frontline demonstrations data (FLD) on mustard. He observed that there was a positive impact of FLD over existing practices for farming community of Lucknow districts. They were motivated by the new agricultural technologies applied in the FLD plots. Mattigatti et al., (2009) analysed and classified the total yield gap in sericulture into three types of yield gaps namely yield gap-I, yield gap-II and yield gap-III. Yield gap-III indicates the yield uncertainty in sericulture. Yield gap-I (33.40\%), is found maximum compared to others due to variation in natural resources. Most of the farmers have taken up the latest mulberry variety and silkworm hybrids realized a low yield gap-II in the study area. There was significant difference among the reasonable, predictable and the actual yield of mulberry. In Gujarat, groundnut and sesame are the two major crops of Saurashtra region, known as "Peanut Bowl" of India. Dhandhalya et al., (2009) measured two types of yield gap in their study. The analysis revealed that a wide yield gap exists in major oilseed crops of study region. The loss in production in both crops was mainly due to biotic, abiotic and socioeconomic constraints. Thus, there is a growing need for evaluation of agricultural research investment and setting priorities for research investment. Choudhary et al., (2009) discussed technology and extension yield gaps in the context of oilseeds. The extensive research has done by Billore et al., (2009) revealed that the highest soybean yield (2705 $\mathrm{kg} / \mathrm{ha}$ ) could be achieved with improved technology. This fact has earlier been reported in the literature stating that the improved package of practices which followed in the national demonstrations for various crops has shown high yield potentials. Interestingly, over the years farmers' practice fetched more yield than that of improved technology.

\section{Materials and Methods}

\section{Yield gap analysis}

The methodology developed by International Rice Research Institute (IRRI) is followed to estimate the magnitude of yield gaps, wherein potential yield, farm yield and farmers' yield are defined as yield obtained at research stations, demonstration plots and farmers' fields, respectively.

$$
\begin{aligned}
& \text { Yield Gap index I }(\%)=\frac{P Y-I V}{P Y} X 100---(3.1) \\
& \text { Yield Gap index II }(\%)=\frac{F V-F V}{T V} X 100----(3.2) \\
& \text { Yield Gap index III }(\%)=\frac{P Y-F V}{P Y} X 100--(3.3)
\end{aligned}
$$


where, PY=Potential yield claimed by breeders, IV=Yield at research station, and $\mathrm{FV}=$ Yield at farmers field. IV and FV are taken from the Front-Line Demonstrations.

Potential yield for each major crop was taken from the respective breeder, yield at research stations (IV) was taken from the KVK and DAATTCs from their Front-Line Demonstrations in three districts of Southern zone and yield at farmers field (FV) will also be noted.

\section{Multiple linear regression}

The model for multiple linear regression, given $n$ observations, is

$\mathrm{Y}_{\mathrm{i}}=\beta_{0}+\beta_{1} \mathrm{x}_{\mathrm{i} 1}+\beta_{2} \mathrm{x}_{\mathrm{i} 2}+\beta_{3} \mathrm{x}_{\mathrm{i} 3}+\ldots \ldots . \beta_{\mathrm{p}} \mathrm{x}_{\mathrm{i} 2 \mathrm{p}}+\varepsilon_{\mathrm{i}}$

for $i=1,2, \ldots . n$

\section{Results and Discussion}

Research on Groundnut, Pulses, Sugarcane and Millets is being carried out by the Regional Agricultural Research Station in Southern Zone of Andhra Pradesh. In this study, Groundnut and Pulses varieties released recently from this Station have been considered for the yield gap analysis. Secondary data is collected from the released proposals of the varieties from respective breeders, data is also taken from the performance evaluations done by the extension Stations (KVK/DAATTC) and the real time data from the farmers fields pertaining to the same crop varieties are also recorded. Yield gap indices are computed for highly popular varieties of groundnut and pulses varieties with help of equations (3.1) to (3.3).Among them the highest yield gap is observed for a blackgram variety TBG-104 among all and summarized in table 1.

From table 1, it is noticed that TBG 104 realized very high yield in farmers' fields whereas its yield is low in almost all experiments in Research and Extension trials during three successive years from its release. It might be due to type of soil, favorable conditions of weather and very good pest management practices. Hence, TBG-104 is considered for the current study to work upon the second objective i.e. to identity the key factors for the yield gap (Fig. 1 and 2).

\section{TBG104, a blackgram variety -at a glance}

In Andhra Pradesh, Blackgram is being grown in 5lakh hectares in three regions i.e. in Coastal region under rabi and rice fallows, in Telangana region as kharif crop and in Rayalaseema under Rabi rainfed and rabi ID since 2005.

Yellow Mosaic Virus (YMV) causes havoc, destroying blackgram sown in hundreds of acres in AP. Most of the high yielding varieties of blackgram grown in Andhra Pradesh such as LBG 623, LBG 645 and LBG 685 are susceptible to Yellow Mosaic Virus (YMV) disease. Farmers switched over to cultivation of Maize under Rice fallows and go for seed guar or Bengal gram in rabi rainfed.

The area under this crop decreased with successive losses. Speculation in market prices, rising cost of cultivation, fertilizer and possibility of soil infertility now have cast a shadow on these non-traditional crops. Research work was initiated in 2009 to develop Yellow Mosaic Virus resistant variety in blackgram using PU-19as donor for YMV.TBG104, YMV tolerant line was identified from PU19x LBG623 cross combination in 2014-15 and released under the name of 'Tirupati Minumu-1' in 2016.

\section{Salient characters of TBG 104}

Developed using parents PU-19 and LBG623 
Tolerant to Yellow Mosaic Virus and photoinsensitive suitable for all seasons (kharif, rabi and summer).

Medium duration (75-80 days) with erect plant type.

Shiny black seed of medium in size.

Dark green leaves lanceolate to oval in shape and pods are densely hairy.

Variety developed through marker assisted selection

Yield potential up to $18-20 \mathrm{q} / \mathrm{ha}$

\section{Advantages}

Popularizing high yielding and disease resistant blackgram line, TBG-104 identified from research work of ANGRAU will be useful to overcome crop shift.

Production and productivity of Blackgram can be increased with coming back of farmers to the cultivation of Blackgram, which is most suited for rice fallows in delta region.

Table.1 Yield gap indices of TBG 104

\begin{tabular}{|c|c|c|c|c|}
\hline $\begin{array}{c}\text { Performance of II over I } \\
\text { During Rabi }\end{array}$ & $\begin{array}{c}\text { Average } \\
\text { yield(q/ac) I }\end{array}$ & $\begin{array}{c}\text { Average } \\
\text { yield(q/ac) II }\end{array}$ & $\begin{array}{c}\text { Yield gap index } \\
(\mathbf{\%})\end{array}$ & Remarks \\
\hline $\begin{array}{c}\text { Yield Gap index I (\%) } \\
\text { Extension(II) over Breeder(I) }\end{array}$ & 6.4 & 3.44 & -46.13 & $\begin{array}{c}46 \% \text { less over } \\
\text { Breeder }\end{array}$ \\
\hline $\begin{array}{c}\text { Yield Gap index II (\%) } \\
\text { Farmer (II) over Extension(I) }\end{array}$ & 3.44 & 8.10 & $\mathbf{1 3 5 . 1 5}$ & $\begin{array}{c}135 \% \text { high over } \\
\text { Extension }\end{array}$ \\
\hline $\begin{array}{c}\text { Yield Gap index III (\%) } \\
\text { Farmer(II) over Breeder(I) }\end{array}$ & 6.4 & 8.10 & $\mathbf{2 6 . 6 9}$ & $\begin{array}{c}27 \% \text { high over } \\
\text { Breeder }\end{array}$ \\
\hline
\end{tabular}

Table.2 Summary of yield obtained from farmers' field

\begin{tabular}{|c|c|c|c|c|c|c|c|c|}
\hline \multicolumn{3}{|c|}{$\begin{array}{c}\text { Impact of type of soil on } \\
\text { yield(q/ac) }\end{array}$} & \multicolumn{3}{|c|}{$\begin{array}{c}\text { Impact of Weed management on } \\
\text { yield }(q / a c)\end{array}$} & \multicolumn{3}{|c|}{$\begin{array}{c}\text { Impact of seed rate on } \\
\text { yield(q/ac) }\end{array}$} \\
\hline Type of soil & Mean & SD & $\begin{array}{c}\text { Weed } \\
\text { management }\end{array}$ & Mean & $\begin{array}{c}\text { Std. } \\
\text { Deviation }\end{array}$ & $\begin{array}{l}\text { seed rate } \\
\mathrm{k} / \mathrm{ac}\end{array}$ & Mean & $\begin{array}{c}\text { Std. } \\
\text { Deviation }\end{array}$ \\
\hline Red soil & 6.30 & 2.541 & No & 6.75 & 3.304 & $8-10$ & 8.33 & .2 .410 \\
\hline Black soil & 7.83 & 1.801 & Yes & 7.22 & 2.074 & $14-16$ & 7.61 & 4.243 \\
\hline Total & 7.14 & 2.253 & Total & 7.14 & 2.253 & Total & 7.14 & 2.253 \\
\hline \multicolumn{3}{|c|}{$\begin{array}{c}\text { Impact of Supplement irrigation } \\
\text { on yield }(q / a c)\end{array}$} & \multicolumn{3}{|c|}{$\begin{array}{c}\text { Impact of } \mathrm{MN}_{2}+\text { pesticides on } \\
\text { yield(q/ac) }\end{array}$} & \multicolumn{3}{|c|}{$\begin{array}{c}\text { Impact of Seed treatment on } \\
\text { yield(q/ac) }\end{array}$} \\
\hline $\begin{array}{c}\text { Supplement } \\
\text { irrigation }\end{array}$ & Mean & $\begin{array}{c}\text { Std. } \\
\text { Deviation }\end{array}$ & pesticides & Mean & $\begin{array}{c}\text { Std. } \\
\text { Deviation }\end{array}$ & $\begin{array}{c}\text { Seed } \\
\text { treatment }\end{array}$ & Mean & $\begin{array}{c}\text { Std. } \\
\text { Deviation }\end{array}$ \\
\hline No & 5.64 & 1.690 & No & 5.20 & 1.398 & No & 5.25 & 1.165 \\
\hline Yes & 8.64 & 1.690 & Yes & 8.75 & 1.357 & Yes & 8.21 & 2.007 \\
\hline Total & 7.14 & 2.253 & Total & 7.14 & 2.253 & Total & 7.14 & 2.253 \\
\hline
\end{tabular}


Table.3(a) Model Summary

\begin{tabular}{|c|c|c|c|c|}
\hline Model & $\mathbf{R}$ & $\begin{array}{c}\text { R } \\
\text { Square }\end{array}$ & $\begin{array}{c}\text { Adjusted } \\
\text { R Square }\end{array}$ & $\begin{array}{c}\text { Std. Error of the } \\
\text { Estimate }\end{array}$ \\
\hline $\mathbf{1}$ & 0.803 & 0.645 & 0.627 & 1.376 \\
\hline $\mathbf{2}$ & 0.853 & $\mathbf{0 . 7 2 8}$ & 0.7 & 1.235 \\
\hline
\end{tabular}

Table.3(b) ANOVA

\begin{tabular}{|c|c|c|c|c|c|c|}
\hline Model & & $\begin{array}{l}\text { Sum of } \\
\text { Squares }\end{array}$ & df & $\begin{array}{c}\text { Mean } \\
\text { Square }\end{array}$ & $\mathbf{F}$ & p-value \\
\hline \multirow[t]{3}{*}{1} & Regression & 68.741 & 1 & 68.741 & \multirow[t]{3}{*}{$36.32 * *$} & \multirow[t]{3}{*}{0.000} \\
\hline & Residual & 37.85 & 20 & 1.893 & & \\
\hline & Total & 106.591 & 21 & & & \\
\hline \multirow[t]{3}{*}{2} & Regression & 77.63 & 2 & 38.815 & \multirow[t]{3}{*}{$25.46 * *$} & \multirow[t]{3}{*}{0.000} \\
\hline & Residual & 28.961 & 19 & 1.524 & & \\
\hline & Total & 106.591 & 21 & & & \\
\hline
\end{tabular}

a. Predictors: (Constant), $\mathrm{MN}_{2}+$ pesticides

b. Predictors: (Constant), $\mathrm{MN}_{2}+$ pesticides, Supplement irrigation

c. Dependent Variable: Yield

Table.4 Coefficients

\begin{tabular}{|c|c|c|c|c|c|c|}
\hline \multirow[t]{2}{*}{ Model } & \multirow[t]{2}{*}{ Factors } & \multicolumn{2}{|c|}{$\begin{array}{l}\text { Unstandardized } \\
\text { Coefficients }\end{array}$} & \multirow{2}{*}{$\begin{array}{c}\text { Standardized } \\
\text { Coefficients } \\
\text { Beta }\end{array}$} & \multirow[t]{2}{*}{ t-value } & \multirow[t]{2}{*}{ p-value } \\
\hline & & $\mathrm{B}$ & Std. Error & & & \\
\hline \multirow[t]{2}{*}{1} & (Constant) & 5.20 & 0.43 & & 11.95 & 0.000 \\
\hline & $\mathrm{MN}_{2}+$ pesticides & 3.55 & 0.58 & 0.80 & 6.02 & 0.000 \\
\hline \multirow[t]{3}{*}{2} & (Constant) & 4.89 & 0.41 & & $11.93 * *$ & 0.000 \\
\hline & MN2+pesticides & 2.71 & 0.63 & 0.61 & $4.29 * *$ & 0.000 \\
\hline & Supplement irrigation & 1.51 & 0.62 & 0.34 & $2.41 *$ & 0.026 \\
\hline
\end{tabular}

*significant at $5 \%$ level

** significant at $1 \%$ level
Fig.1 Performance at research trials

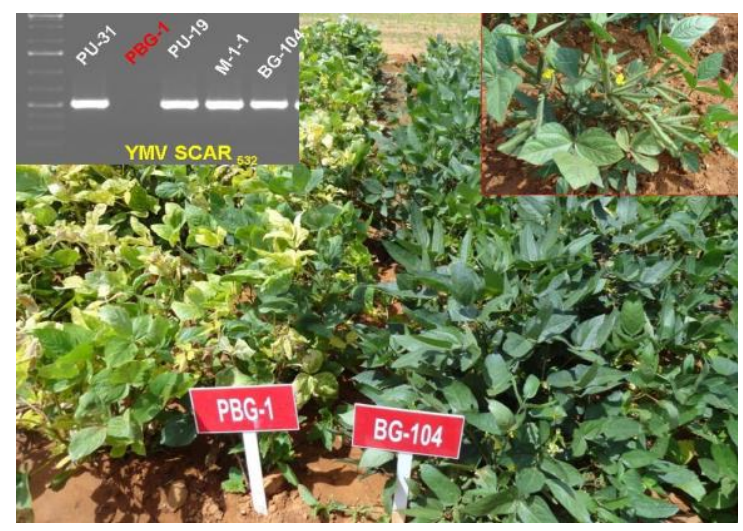


Fig.2 Performance at Farmer's field

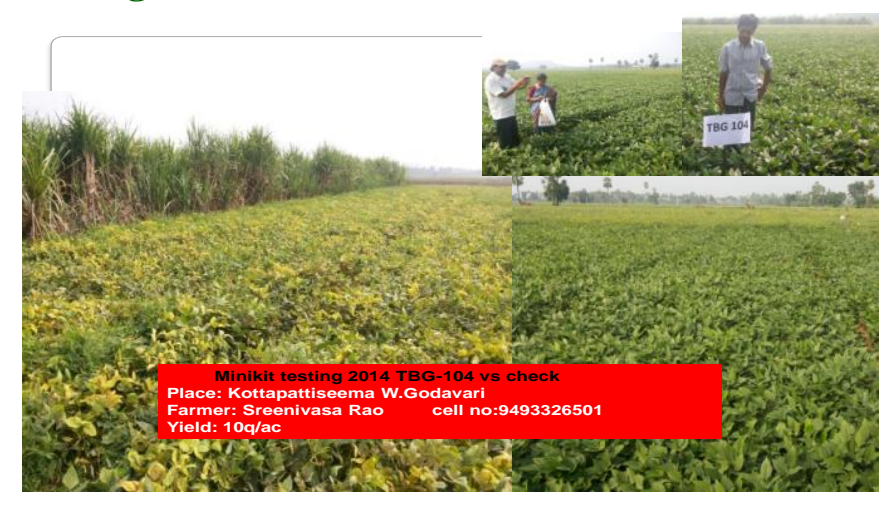

Inclusion of this crop in cropping systems will promote soil health and answer to the farming community who are facing severe crop loss due to this disease and finally human health.

\section{Success story of blackgram TBG-104}

Developed YMV resistant blackgram culture TBG-104 using biotechnology tools. Its performance is found promising in minikit and farmers expressed satisfaction

\section{Performance of TBG-104 in farmers' fields}

Primary data was collected from 52 farmers of TBG104 in three districts of Southern Zone of Andhra Pradesh at their fields. Data pertaining to seven variables viz., type of soil, seed rate, seed treatment, weed management, supplement irrigation, two micronutrient sprays $\left(\mathrm{MN}_{2}\right)$ and pesticide application and yields are noted. The range of final yield of TBG 104 is noticed as 5 to 12 quintals per acre. Summary of yield in terms of mean and standard deviation as per the six factors is presented in table 2 .

From table 2, it is identified that the average yield in Black soils is observed as 7.83 quintals per acre whereas it is only 6.3 quintals per acre in Red soils. This indicates nearly $24 \%$ more yield is observed in Black soils. The impact of seed rate is also observed in that $9 \%$ yield enhancement is noticed when the seed rate is 14-16 kgs per acre than that of 8-10 kgs per acre. Similarly, in majority of the fields the impact of seed treatment is also observed in such a way that $56.4 \%$ of yield protection is saved in critical situations. The impact of weed management is noticed as $7 \%$. Finally, it is observed that there is significant impact of supplement irrigation by $53.23 \%$ and with the usage of two sprays of micronutrients and pesticides at recommended level nearly $68 \%$ of the yield is retrieved significantly.

\section{Yield gap model for TBG 104}

Further, a Multiple Linear Regression model is constructed using equation (3.4) on yield with six factors using SPSS-20 (trial version) in stepwise approach to identify the significant factors for the higher yields realized in the farmers' fields. The model summary is given in table 3(a), 3(b) to 4 .

Model summary gives details of the overall correlation between the variables left in the models and the dependent variable. With model-2, 70\% of variation in the yield can be explained using two independent variables such as $\mathrm{MN}_{2}+$ pesticides, Supplement irrigation. That means with the introduction of the second variable i.e supplement irrigation the variance is enhanced from $63 \%$ to $70 \%$ that indicates nearly $7 \%$ of the variation in the yield is explained by the variable supplement irrigation. As it is optimally good, we can rely on this model.

The table 3(b) is the F-test for the adequacy of the model. The linear regression's F-test has the null hypothesis that the model explains zero variance in the dependent variable (in other 
words $\mathrm{R}^{2}=0$ ). The F-test is highly significant; thus, one can assume that the model explains a significant amount of the variation in the yield. Hence the model is adequate.

Finally, the table 4 shows the regression coefficients that is quantity of contribution from each independent variable towards dependent variable i.e yield. The model can be written as;

Yield $=4.896+2.714^{* *}\left(\mathrm{MN}_{2}+\right.$ pesticides $)+$ $1.519^{*}$ (supplement irrigation)

From the model, it is noticed that the potential yield of this variety is approximately $4.9 \mathrm{q} / \mathrm{ac}$ irrespective all other management practices. Due to supplement irrigation nearly 1.5 quintals per acre can be protected while 2.7 quintals per acre can be protected with the application of two sprays of micronutrients and usage of pesticides at recommended level.

In conclusion from this study it was found that the major contributors for the yield gap between potential and observed yield of TBG-104 in the farmers' field as two sprays of micronutrients along with pesticide applications at recommended level and supplement irrigation at the time of no rains. Moreover, cultivating TBG-104 in the black soils will further boost up the yield. So, this variety became a boon for the farmers in realizing very good yields and encouraged them to cultivate blackgram in southern zone despite their fear owing to historical failures in blackgram especially due to the Yellow Mosaic Virus.

\section{References}

Aggarwal, P.K., K.B. Hebbar; M.V. Venugopalan; S. Rani; A. Bala; A. Biswal and S.P. Wani. 2008. Quantification of yield gaps in rain-fed rice, wheat, cotton and mustard in India. International Crops Research Institute for the Semi-Arid Tropics. Global Theme on Agro-ecosystems Report No. 43. Andhra Pradesh, India.

Billore, S.D., A.K. Vyas and O.P. Joshi. 2009. Assessment of improved production technologies of soybean on production and economic potentials in India. Journal of Food Legumes, 22(I): 49-52.

Choudhary, A.K., D.S. Yadav and A. Singh. 2009. Technological and extension yield gaps in oilseeds in Mandi district of Himachal Pradesh. Indian J. Soil Cons., 37(3): 224-229.

Dhandhalya, M.G. and R.L. Shiyani. 2009. Production potentials, yield gaps and research prioritization of production constraints in major oilseed crops of Saurashtra region. Indian J. Agric. Res., 43(1): 18-25.

Jha, Girish; Roy Burman, Rajarshi; Dubey, Shantanu; Singh, Gajab. (2012). Yield Gap Analysis of Major Oilseeds in India. 6. 209-216.

Kiresur, V.R., S.V. Ramanna Rao and D.M. Hedge. 2001. Improved technologies in oilseeds production-An assessment of their economic potentials in India. Agricultural Economic Research Review, 14(2): 95-108.

Mattigatti, R., B.P. Veerabhadrappa and C. K. Renukarya. 2009. Yield gap in sericulture in Karnataka - An economic analysis. Karnataka J. Agric. Sci., 22(5): 1046-1050.

Singh, S.N., V.K. Singh; R.K. Singh and K.R. Singh. 2007. Evaluation of on-farm front line demonstrations on the yield of mustard in central plains zone of Uttar Pradesh. Indian Res. J. Ext. Edu., 7(2\&3): 79-81.

\section{How to cite this article:}

Lavanya Kumari, P. and Prasanthi, L. 2020. Yield Gap Analysis of TBG-104 (Blackgram variety) in Southern Zone of Andhra Pradesh. Int.J.Curr.Microbiol.App.Sci. 9(09): 1757-1763. doi: https://doi.org/10.20546/ijcmas.2020.909.219 